\title{
The effect of Training on Reducing Barriers to the implementation of the Value Added Tax Act among Taxpayers in Iran
}

\author{
${ }^{1}$ Zeinolabedin amini sabegh, ${ }^{2}$ Reza dalirian, ${ }^{3}$ Reza shafizadeh \\ ${ }^{1,3}$ Departmen $^{t}$ of Public management, Islamic Azad University, saveh branch, Saveh, Iran \\ ${ }^{2}$ Student of Education management, Islamic Azad University, saveh branch, Saveh, Iran
}

\begin{abstract}
The main objective of this study is to explain the effect of training on reducing barriers to the implementation of the Value Added Tax Act in Iran which is conducted with descriptive - survey method. Statistical society consists of the all managers and staff of the Ministry of Economy and Finance whose performance of their organizational units relates to the implementation of the Value Added Tax Act and their number is 712 people and 250 people of them were selected as a sample. The procedure of sampling is random cluster sampling. Researcher made questionnaire was used to collect the data containing 23 questions. Its validity by supervisors, advisors and some experts and its reliability by using Cronbach's alpha experimentally performed for 30 people and obtained 0.817 have been approved. Data obtained from the chi-square test (chisquare), binomial test and Friedman test were analyzed using SPSS software. The results of this study indicate that training is effective on reducing barriers to the implementation of the Value Added Tax Act. Also the effect of training on staff based on the software and hardware aspects, taxpayers and informing systems for the implementation of the Value Added Tax Act was approved and the effect of training on top management of organizations to support the implementation of the Value Added Tax Act was not confirmed.
\end{abstract}

Keywords: Training, Value Added Tax Act, Ministry of Economy and Finance.

\section{Introduction}

Important source of government revenue is tax that is collected under different titles. Revenue from taxes comprises a significant portion of the state budget; in countries where tax has a legal and public system, more than $60 \%$ of general budget comes from taxes and attention to this issue is so important that in general, it can be said the stability and continuity in collecting taxes leads to the stability in government planning and provision of services required for society in various fields. But it seems that in today's countries success in collecting taxes and increasing government revenues cannot only be the goal of the tax system; but also how to collect taxes and tax revenues as well as imbalance of government costs and revenues are among the most important economic issues that must be considered due to the radical effects which this issue can have on the economy of a society. Due to the inability of the tax system and limitations which had been applied on tax law in the past, amending the law of direct taxation can be regarded as one of the cases in order to reach the modern economic goals in countries, based on which rates and tax exemptions are also faced with fundamental changes, in addition to the fundamental changes in the management processes and tax affairs administration. Thus, recently the design and implementation of the Value Added Tax in the realm of public finance issues have been discussed in our country. In this regard, this study has paid attention to the effect of training on reducing barriers to the implementation of the Value Added Tax Act in Iran.

\section{Problem Statement}

The subject of tax revenues and imbalances in government costs and revenues are among the most problematic social issues that have been discussed so far. Issues such as rising incomes, encouraging production and investment, reducing inequalities and promoting social welfare are of the main point related to tax system and its social function. In fact, important source of government revenue is tax that is collected under different titles. But it seems that in today's countries success in collecting taxes and increasing government revenues cannot only be the goal of the tax system; but also how to collect taxes and tax revenues as well as imbalance of government costs and revenues are among the most important economic issues that must be considered due to the radical effects which this issue can have on the economy of a society. Therefore, generally it can be said that amending the law of direct taxation can be regarded as one of the most problematic cases in order to reach the modern economic goals in countries. In this regard, recently the design and implementation of the Value Added Tax in the realm of public finance issues have been discussed.

Significant expansion and development of Value Added Tax perhaps can be known as the most problematic tax development in the late twentieth century. This tax for the first time was designed to overcome 
financial problems in Germany by Siemens in 1951. But despite the countries' desire to know how it is structured, the tax was officially introduced from 1954 onwards at the countries' taxation system.

Value Added Tax is an indirect tax on domestic consumption and sales of goods and services, but unlike the simple and dispersed taxes which get the various rates based on the type of goods, in a single step transfer and exchange of goods hits its worth, this tax is a kind of multistage tax and is created in terms of the value added at each stage of production and finishing until final consumption, and at that point, it is also taxable. In other words, Value Added Tax is a kind of tax on the sale price that its tax burden is borne by the final consumer and value added of firms, namely the difference between the proceeds from the sale of goods and services and total costs paid for the purchase of inputs (excluding human force) are received. In general it can be said; Value Added Tax is not only relatively simple taxation, but also is the most common in today's world. From an economic perspective, value added is the difference between the value of output and value of input. But the legislation, in terms of providing executive optimal performance attitude, this definition is presented based on accounting standards and relying on billing methods. Accordingly, the value added is defined as the difference between the value of goods and services with the value of goods and services purchased by a person in a given period. In Iran, in order to reduce reliance of state budget on oil revenue and in accordance with the guidelines of the Third Development Plan Document,It was also decided that the share of tax revenues in the combination of revenue sources to be increased with the expansion of tax bases through the Value Added Tax. However, studies in recent years indicate that according to government efforts, this law has not been fully implemented again and there are some barriers to the implementation of Value Added Tax Act such as weaknesses in information systems, lack of appropriate software systems, lack of support from top management organizations, lack of equipment and hardware and lack of trained and qualified staff. In this regard, the results of preliminary observations and interviews of researcher with the tax authorities suggest that one of the most important aspects of the executive section of Value Added Tax and creating more information is through the training for those who are working with Ministry of Economic Affairs and Finance and different tax parts. Therefore the researcher in this study seeks for an answer to this question that whether the training is effective in reducing barriers to the implementation of Value Added Tax Act or not?

\section{Hypothesizes \\ Main hypothesis}

Teaching is effective on reducing barriers to the implementation of the Value Added Tax Act.

\section{Sub-hypotheses}

1- Training on employees based on the hardware and software aspects of the implementation of the Value Added Tax Act is effective.

2-Training on taxpayers is effective in order to implement the Value Added Tax Act.

3-Training on the top management of organizations is effective in order to support the implementation of the Value Added Tax Act.

4-Training on informing systems is effective in order to implement the Value Added Tax.

\section{Research Methodology}

In this study, at first subject - related sources were collected through the library sources and after reviewing the research relevant to internal and external background, statistical population appropriate with the research topic was selected and from which the sample was selected. Then, the method was determined according to its objective and data collection methods, and then data analyzing background was prepared by collecting data through questionnaire. At the next step, data analyzing resulted in the findings. And finally the study was concluded. The present research is a descriptive research. The purpose of this study is to describe the objective, real and regular features of a situation or issue. In other words, the researcher tries to report what there is, without any interference or subjective inference and take objective results from the position. So, the research method is descriptive - survey and because these results can also be used, it is an applied research. In this study, the statistical society consists of the all managers and staff of the Ministry of Economy and Finance whose performance of their organizational units relates to the implementation of the Value Added Tax Act and their number is 712 people. In this research, 249 people of them were selected as a sample by using statistical formulation that 260 questionnaires were distributed to increase the reliability of responsiveness of all participants and after removal of undesirable questionnaires, the sample size was determined as 250 people. The sampling method used in this study is random cluster sampling. The number of sample is according to this type of organizational units.

In this study, data were obtained through questionnaires. For this purpose, a questionnaire with 23 questions was prepared for the community. Raised questions for each hypothesis are described in Table 1. 
Table 1: Questions for each hypothesis

\begin{tabular}{|c|c|}
\hline Questions & Sub-hypotheses \\
\hline 3، 4، 6، 9، 10، 12، 15، 16، 18، 21 22 & First \\
\hline 19 ،13، 7، & Second \\
\hline $17 ، 11 ، 5$ & Third \\
\hline 23 20 20، 14، 8 & Fourth \\
\hline
\end{tabular}

In present paper, after the study of library resources we talked with several teachers about questionnaire preparation and esteemed supervisors and advisors were informed about the initial questionnaire and they did a complete reform. To ensure the content validity of the questionnaire, the idea of some professors who had also investigated the questionnaire was achieved. They all confirmed the content of the questionnaire. Finally, the questionnaire was prepared and distributed. In this study, Cronbach's alpha method was used for calculating the reliability that its value was 0.817 for whole questionnaire in experimental performance for 30 people. Indeed, the more the percentage is closer to one, the more the reliability of questionnaire is. In fact, Cronbach's alpha analysis shows that questionnaire has a good reliability. In the following, the value of Cronbach's alpha is calculated for each hypothesis and is shown in Table 2.

Table 2: The value of Cronbach's for each hypothesis

\begin{tabular}{|c|c|}
\hline Alpha Value & hypothesis \\
\hline $0 / 724$ & First \\
\hline $0 / 843$ & Second \\
\hline $0 / 776$ & Third \\
\hline $0 / 867$ & Fourth \\
\hline
\end{tabular}

In this study, the chi-square test (chi-square), univariate test and binomial test were used to test hypotheses and Friedman test used to rank the dimensions.

\section{Hypothesizes Test}

- The first sub-hypothesis of the research is as follows:

"Training on employees based on the hardware and software aspects of the implementation of the Value Added Tax Act is effective"

This hypothesis is defined in the form of statistical hypothesis as follows:

There is no relationship between the training of employees and the performance of Value Added Tax Act. HO: There is a relationship between the training of employees and the performance of Value Added Tax Act. H1:

Since HO is rejection region and $\mathrm{H} 1$ is acceptance region of our hypothesis and in the other hand, $\alpha$ is 0.05 , the critical region can be determined by $\chi 2$ table. Degree of freedom is also 4 at this hypothesis, therefore according to the $\chi 2$ table; table statistic will be equal with $9 / 49$. Also, according to the obtained results, the test statistic is derived as follows:

$\chi 2=\sum \frac{(\text { Foi }- \text { Fei }) 2}{\text { Fei }}=21.8$

Since the $\chi 2$ calculated with $5 \%$ error and degree of freedom 4 is larger than $\chi 2$ table $(21.6 \geq 9 / 49)$, it can be said that it is located at H1 region, in the other word the obtained amount is located at the critical region. Therefore, the relationship between training of employees and the performance of Value Added Tax Act is confirmed.

\section{- The second sub-hypothesis of the research is as follows:}

"Training on taxpayers is effective in order to implement the Value Added Tax Act."

This hypothesis is defined in the form of statistical hypothesis as follows:

There is no relationship between taxpayers and the performance of Value Added Tax Act. HO:

There is a relationship between taxpayers and the performance of Value Added Tax Act. H1:

Degree of freedom is also 4 at this hypothesis, therefore according to the $\chi 2$ table; table statistic will be equal with $9 / 49$. Also, according to the obtained results, the test statistic is derived as follows:

(Foi - Fei) 2 
$\chi^{2}=\sum \frac{}{\text { Fei }}=17.2$

Since the $\chi^{2}$ calculated with $5 \%$ error and degree of freedom 4 is larger than $\chi^{2}$ table (17.2 $\left.\geq 9 / 49\right)$, it can be said that it is located at $\mathrm{H} 1$ region, in the other word the obtained amount is located at the critical region. Therefore, the relationship between taxpayers and the performance of Value Added Tax Act is confirmed.

- The third sub-hypothesis of the research is as follows:

"Training on the top management of organizations is effective in order to support the implementation of the Value Added Tax Act. “

This hypothesis is defined in the form of statistical hypothesis as follows:

There is no relationship between the top management of organizations and the performance of Value Added Tax Act. HO:

There is a relationship between the top management of organizations and the performance of Value Added Tax Act. H1:

Degree of freedom is also 4 at this hypothesis, therefore according to the $\chi^{2}$ table; table statistic will be equal with $9 / 49$. Also, according to the obtained results, the test statistic is derived as follows:

$\chi^{2}=\sum \frac{(\text { Foi }- \text { Fei }) 2}{\text { Fei }}=7.8$

Since the $\chi^{2}$ calculated with $5 \%$ error and degree of freedom 4 is smaller than $\chi^{2}$ table $(9 / 49 \geq 7.8)$, it can be said that it is located at $\mathrm{H} 0$ region; in the other word the obtained amount is not located at the critical region. Therefore, the relationship between the top management of organizations and the performance of Value Added Tax Act is not confirmed. So the binomial test is not also done and the overall result would be that there is no reason to say "Training on the top management of organizations is effective in order to support the implementation of the Value Added Tax Act.

- The fourth sub-hypothesis of the research is as follows:

"Training on informing systems is effective in order to implement the Value Added Tax"

This hypothesis is defined in the form of statistical hypothesis as follows:

There is no relationship between the informing systems and the performance of Value Added Tax Act. HO:

There is a relationship between the informing systems and the performance of Value Added Tax Act. H1:

Since $\mathrm{HO}$ is rejection region and $\mathrm{H} 1$ is acceptance region of our hypothesis and the degree of freedom is also 4 at this hypothesis, therefore according to the $\chi 2$ table; table statistic will be equal with $9 / 49$. Also, according to the obtained results, the test statistic is derived as follows:

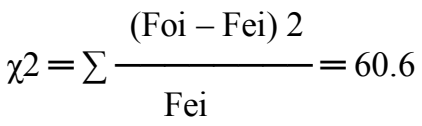

Since the $\chi^{2}$ calculated with $5 \%$ error and degree of freedom 4 is larger than $\chi^{2}$ table $(60.6 \geq 9 / 49)$, it can be said that it is located at $\mathrm{H} 1$ region, in the other word the obtained amount is located at the critical region. Therefore, the relationship between the informing systems and the performance of Value Added Tax Act is confirmed.

\section{- The main hypothesis:}

"Teaching is effective on reducing barriers to the implementation of the Value Added Tax Act."

This hypothesis is defined in the form of statistical hypothesis as follows:

There is no relationship between Teaching and the performance of Value Added Tax Act. HO:

There is a relationship between Teaching and the performance of Value Added Tax Act. H1:

Since $\mathrm{HO}$ is rejection region and $\mathrm{H} 1$ is acceptance region of our hypothesis and the degree of freedom is also 4 at this hypothesis, therefore according to the $\chi 2$ table; table statistic will be equal with $9 / 49$. Also, according to the obtained results, the test statistic is derived as follows: 
$\chi^{2}=\sum \frac{(\text { Foi }- \text { Fei }) 2}{\text { Fei }}=27.2$

Since the $\chi^{2}$ calculated with $5 \%$ error and degree of freedom 4 is larger than $\chi^{2}$ table (27.2 $\left.\geq 9 / 49\right)$, it can be said that it is located at $\mathrm{H} 1$ region, in the other word the obtained amount is located at the critical region. Therefore, the relationship between training and the performance of Value Added Tax Act is confirmed.

\section{Friedman test}

As discussed in Chapter III in this study, the Friedman test was used to rank the hypotheses (indexes) from perspective of whole sample and determine whether the difference between them is significant or not? In this case the hypotheses are as follows:

HO:There is no relationship between the importance degree of barriers to the implementation of Value Added Tax Act which were influenced by training.

H1:There is a relationship between the importance degree of barriers to the implementation of Value Added Tax Act which were influenced by training.

The following results have been obtained from analyzing data by using SPSS software which shows the priority of each hypothesis based on the mean rank of the sample group. As shown in Table 3, the sample group has known the training of taxpayers as the most important factor because the mean rank of Friedman is less than all. Other results are shown in Table 4.

Table 3: priorities identified from perspective of sample group

\begin{tabular}{|c|c|c|c|}
\hline $\begin{array}{c}\text { Ordinal ranking in } \\
\text { terms of } \\
\text { importance }\end{array}$ & $\begin{array}{c}\text { Ranking by using } \\
\text { mean }\end{array}$ & $\begin{array}{c}\text { Number of sample } \\
\text { group }\end{array}$ & Indexes \\
\hline 2 & 1.67 & 250 & Training of employees \\
\hline 1 & 1.32 & 250 & Training of taxpayers \\
\hline 4 & 4.67 & 250 & Training of top management \\
\hline 3 & 3.27 & 250 & Training of informing systems \\
\hline
\end{tabular}

Friedman test, in addition to determine the priority, determines whether there is a difference between the ranks or not? It can be decided according to the table 4.9, because the amount of calculated statistic is 44.6 , more than statistic table, at the error level of $5 \%$ and degree of freedom 4 , therefore the hypothesis $\mathrm{H} 1$ is confirmed and we conclude that there is a significant relationship between the importance degree of different factors. And the low significance level is the other reason for this speech.

Table 4: Friedman test statistic for sample group

\begin{tabular}{|c|c|c|c|}
\hline significance level & $\begin{array}{c}\text { Degree of } \\
\text { freedom }\end{array}$ & $\begin{array}{l}\text { Amount of } \\
\text { statistic }\end{array}$ & \\
\hline $0 / 000$ & 6.4 & 44.6 & $\begin{array}{c}\text { Whole } \\
\text { sample }\end{array}$ \\
\hline
\end{tabular}

\section{Conclusion}

The results indicate that the training is effective on reducing barriers to the implementation of the Value Added Tax Act. Here it is tried to briefly examine the results. In this study, a hypothesis and four subhypotheses were analyzed by using statistical methods and according to the researcher's work experience from society and also based on researcher's personal observations, It could be argued about the research hypotheses that low experience of executive organizations and their employees in the implementation of Value Added Tax , lack of companies supporting the financial software of organizations and institutions, lack of facilities and equipment in providing appropriate invoices for purchase and sales, lack of developing an effective system of reward or punishment for tax officials, the rigidity of the financial software at institutions and organizations, lack of control mechanisms against tax evasion, lack of training and familiarity of tax officials with tax periods, lack of attention to detail in developing the tax software, lack of tools and mechanisms to increase the assurance in tax collection; lack of revision in the new tax rules at agencies performing Value Added Tax Act and negative publicity about the increase of government revenues and its negative impact on the implementation of 
Value Added Tax are among the obstacles to implementation of the Value Added Tax Act which will be decreased by training staff of the Ministry of Economy and Finance and its subsidiary organizations.

The results show; feelings of inequity and unfairness of this kind of tax by taxpayer, different abilities in taxpayers payment and fixed rate of Value Added Tax, excessive transparency of taxpayer's financial performance and lack of attention and encourage of taxpayers to use the certifies auditors' tax services are among the obstacles to implementation of the Value Added Tax Act which will be decreased by training taxpayers. The results of this study indicate that the lack of top management's support from excessive transparency of his/her organization's financial performance, lack of executive guarantee by the political systems and decrease of investment and production incentives in organizations' managers are not as barriers to implementation of Value Added Tax . The results of this study indicate that lack of adequate informing about the base and rate of tax, unclear tax exemptions, and weakness of informing about them, weakness of informing on the origin or destination at the time of taxation, lack of adequate informing about double taxation and lack informing on how to transfer the amount of taxes to buyers and consumers are among the obstacles to implementation of the Value Added Tax Act which will be decreased by training employees and taxpayers and adequate informing.

\section{Reference}

[1]. Alan, A. T. (2007),Value Added Tax: International Practice and Problems, IMF.

[2]. Conell, J. \& Hannif, Z. (2009), Call Centers, Quality of Work life and HRM Practics, Employee Relations, 31 (4): 363-381.

[3]. Henri, J. F. (2006), Organizational Culture and Performance Measurement Systems, Accounting, Organizations and Society, 31(4).PP:77-103

[4]. Kaplanoglou, G. \& Newbery, D. M. (2006),Indirect Taxation in Greece: Evaluation and Possible Reform, CES Working Paper.No.661.

[5]. Marlen, B. (2010), VAT Fraud:The South American Experience, Vat Monitor

[6]. Moy, J. M. \& Henkin, B. A. (2006),Exploring Associations Between Employee Empowernment And Interpersonal Trust in Managers, Journal of Management Development, 25 (2). 101-117. 